れており，正確な距離計測が可能であった。(2)3D-アンギオによ り，脳動脈瘤の起始部の颜断が容易に行えた。 (3) 血管狭窄部の血栓 の状態が，仮想内視鏡モード(内腔表示)で観察できた. (4)脳動脈瘤 の3D-アンギオは，手術またはIVRの決定に有用であった。

$218 \mathrm{CR}$ 装置用階調ファントムの作成

大阪府立羽曳野病院·放射線科 錦織光司，藤岡富雄，谷口義則 山口道弘

【目的】胸部CR装置における階調の調整は，装置の設置時における画 像作成や装置の経時的変化をみるうえで重要である，今回われわれ はCR装置がオートで肺野認識をし，階調を細く測定できるファント ムを作成したので報告する。

【方法】1)材質を耐久性と材料の入手しやすさからアクリルと鉛に決 め，標準的な体系の人体と同等の肺野濃度を示すようにS/F画像から アクリル厚を決める。2)上部はCRが自動で肺野認識でき，下部は階 調の変化を観察できるようファントムの形状を決定する．3）この ファントムの再現性をみるため, 日差変動および同一日の 100 回曝 写のS 值とG值の变動をみる。4)ファントムを撮影し, 階調が観察で きる下部の濃度とアクリル厚の入出力特性をみる。

【結果】1) S/F系画像から肺野部のアクリル厚は $8 \mathrm{~cm}$ で濃度1.75とな り，ファントム上部の厚みを $8 \mathrm{~cm}$ とした。 2) CR 装置が肺野認識する ためのファントムの形状は肺野, 胸郭, 横隔膜, 腹壁の構成となっ た. 3）日差変動 S值 AV361 SD 16.5, G值 AV1.74 SD0.01 連続曝射変動 S值 AV387 SD 8.3, G值 AV1.71 SD 0.02 4) 入出力特性は以下に示す.

【結論】1)胸部CR階調用ファントムについて検討した。2)CR装置が 自動で肺野認識をするためには，肺，胸郭，横隔膜および腹壁の形 状が必要であった３）ファントムが常に安定したS值，G值を呈する ことで, 階調調整の再現性を示唆できた，4)ファントムの入出力特 性からCR装置の階調調整が容易になった。

\section{$219 \mathrm{CR}$ 装置用階調ファントムの応用}

大阪府立羽曳野病院・放射線科 錦織光司, 藤岡富雄, 谷口義則 山口道弘

【目的】胸部CR装置にお拈階調調整は, 従来, アクリル板等によっ て行われてきたが, 胸部認識のできるものはなかった，今回われわ れは胸部認識可能な自作ファントムを用い, 胸部CR装置の階調調整 を行ったので報告する.

【方法】1) 臨床画像から絴隔と肺野の特徵抽出を行い, それぞれ濃度 の階調調整処理域を決定する．2)設定したそれぞれの階調処理の調 整範囲を最大から最小まで均等 4 分割し, 階調処理の制御信号の関 数化を行い, 自作ファントムによる出力特性を求める. 3) その後, それぞれの関数で臨床画像を出力し, 現在作成している画像を基準 に縦隔と肺野の描出が向上していると思われる関数を選択し, 評価 を行った。

【結果】1)それぞれの特徵抽出の結果は, 縦隔の場合, (1) 気管0.67, (2) 気管分岐部 0.56 , (3) 大動脈弓部 0.78 , (4) 第 9 胸椎 0.53 , (5) 第 12 胸椎, (6) 左心室 0.67 , (7)下行大動脈 0.49 となり, 濃度 0.39 が処理域 の中心となった．肺野の場合，右第 6,7 後肋骨間で外側より $2 \mathrm{~cm}$ の 末梢血管の濃度をその近傍の胁骨濃度と決め, その近傍の肺野濃度 と比較すると, (1) 肺野平均濃度1.57, (2)末梢血管平均濃度 1.30 とな り，濃度1.35が処理域の中心となった。2)自作ファントムの出力特

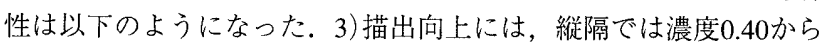
0.80 までのコントラストを高くするほど，識別能が上昇し，肺野で は濃度1.35を基準に上下 $3 \%$ 以内の調整が有用であった。

【結論】1)自作ファントムを使用して縦隔部抢よび肺野の描出向上を 目的とした階調調整を検討した。2)自作ファントムの入出力特性か ら，階調調整域の濃度変化が客観的に観察できた。3)描出向上に

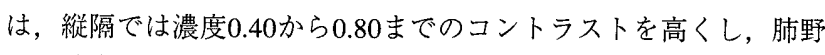
では濃度1.35を基準に上下 $3 \%$ 以内の調整が有用であった。

\section{0 異なるCRシステムの比較検討一第 1 報 胸部写真の比較検} 討 -

日本大学医学部附属練馬光が丘病院・放射線部 保積悦子, 中川眞豪 磯川浩治，渡邊典子，田所秋宏，樫村太陽，渡部一宏，平野壯幸 【目的】京都大学(胸部疾患研究所)の視覚的評価法を用いて, 胸部写 真についてコダックデイジタルサイエンスCRシステム 400 (コダック (株))とFCR9000システム (富士フイルムメデイカル(株))との比較検 討を行い, 胸部写真の最適化を図った。

【方法】同一条件で撮影した胸部写真を, 肺野部末梢側, 肺野部縦隔 側, 縦隔部の三つの領域に分類してそれぞれの部位において分解能 の評価を行い, 粒状性, 鮮鋭度, コントラストについてもそれぞれ 視覚的評価を行った。この評価によって得られた結果を考慮して, それぞれのシステムに扔いて胸部パラメー夕を変化させ，写真の最 適化を図った。な拈，胸部写真は入職検診時 (3月実施) と職員検診 時 $(8$ 月実施)のものを使用した.

【結果】Fuji CRシステムでは, 被写体厚にかかわらず肺野部において 評価が高く維隔部において評価が低くなった，Kodak CRシステムで は，被写体厚による評価の違いが生じた，被写体厚が厚い場合に， 肺野部において評価が低い傾向があり，コントラストにおいても評 価が低くなるという結果となった。

【考察】Fuji CRシステムについては商品化からの年数が長くほとんど 改善点がなかった．Kodak CRシステムについては今回の比較検討に より，視覚的評価の高い写真を得ることができた。

\section{1 高エネルギーX線を用いたCR喉頭(正面)像の基礎的検討} 北海道大学医学部附属病院·放射線部菊池務，勝本 尚、佐賀和高 【目的】X線喉頭正面像では喉頭後方の頸椎骨像が重り読影の障害と なり診断能を左右することが多い。したがって通常はX線管電圧 $140 \mathrm{kV}(\mathrm{Cu} /$, Al附加フィル夕)で高圧撮影が行われているが読影に十 分な画質とは言い難い現状にある。本研究ではStrage-Phosphor Radiography (以下，CR) と高エネルギーX線を組み合わせ，喉頭部空 気透過像を従来高圧撮影像と同一濃度で表示した時, 周囲軟部組織 (または軟部腫瘍)のcontrast (描出能)を向上すると同時に，骨像の信 号強度を従来の喉頭像より大幅に減衰することが可能か否かを検討 した。

【方法】各種 $\mathrm{X}$ 線管電圧および高エネルギー X線 $(140 \mathrm{kV}, \mathrm{Cu}$ ： $1.5 \mathrm{~mm}, \mathrm{Al}: 0.5 \mathrm{~mm})$ の実測X線スペクトル (peak值：拈よそ60keV, 半值幅: 約 $50 \mathrm{keV}$ ) と骨, 筋肉, 脂肪の質量エネルギー吸収係数を用 いて, 各組織のX線吸収比がどのように変化するかcomputedsimulation studyにより算出した。この結果をもとに疑似腫瘤を貼付 したファントム像を撮像し, 得られたCR信号を $\gamma$ 変換表示した後, 出力フィルム像により描出能を評価した.

【結果】computed-simulation studyでは，X線の線質が硬くなると各組 織のX線吸収は著しく低下した。しかし，信号強度が急激に低下す る骨に対し, 軟部組織(筋肉, 脂肪)の低下率は緩やかであった。こ のことは，低下したcontrastを適切に増幅すると目的にかなう画像が 得られる可能性を示唆した. ファントム実験の結果は同様の傾向を 示した.

【結論・考察】高エネルギーX線の最適化やこれに付随する $\gamma$ 変換処 理の程度など今後の検討課題は多いが，軟部組織(軟部腫湟)の高い contrastを保持しながら, 骨陰影を著しく隇衰させたX線喉頭像を得 ることへの可能性が示された. 本法はsingle exposure dual energy subtraction法とは異なり，簡易で鮮鋭度のよいX線喉頭像が期待され る. 